\title{
PENGABDIAN KEPADA MASYARAKAT SISTEM INFORMASI KEGIATAN TERPADU (SIKAT) REMAJA SINODE GMIM
}

\author{
Komansilan Edmond dan Raintung Arnetha ${ }^{1}$ \\ ${ }^{1}$ Program Studi Teknik Elektro Universitas Pembangunan Indonesia \\ e-mail: ekomansilan@gmail.com
}

\begin{abstract}
Abstrak
Komisi Pelayanan Remaja Sinode GMIM merupakan bagian dari pelayanan Gereja Masehi Injili di Minahasa yang ada di Propinsi Sulawesi Utara. Dalam pelayanannya dibawah naungan Gereja Masehi Injili di Minahasa (GMIM) Komisi Pelayanan Remaja mengkhususkan pelayanannya pada anak remaja berusia 12-16 tahun sesuai dengan tata gereja GMIM. Dengan keberadaan teknologi saat ini, Komisi Pelayanan Remaja Sinode GMIM membangun suatu sistem untuk membantu pelaksanaan setiap kegiatan atau program yang dilaksanakan berupa Sistem Informasi Kegiatan Terpadu (SIKAT). Pengembangan Sistem Informasi ini belum banyak diketahui oleh remaja maupun pembina remaja, sehingga dalam pelaksanaannya masih ada jemaat atau pembina yang belum menggunakan sistem ini. Oleh karena itu pengembangan sistem informasi ini perlu diikuti dengan pelatihan cara menggunakan sistem informasi kegiatan terpadu (SIKAT), sehingga dalam pelaksanaan kegiatan Remaja Sinode GMIM semua dapat terdata dengan baik lewat sistem yang sudah dibangun. Luaran Kegiatan adalah Aplikasi Sistem Informasi Terpadu Remaja Sinode GMIM.
\end{abstract}

Kata Kunci: Sistem, Aplikasi, Pelatihan, Penerapan, GMIM

\section{A. Pendahuluan}

Sistem informasi dan teknologi informasi merupakan hal fundamental yang harus dimiliki untuk melakukan kegiatan operasional suatu organisasi atau perusahaan. Saat ini sistem informasi sudah menjadi kebutuhan dasar bagi perusahaan atau organisasi dan hal ini juga dilihat oleh Komisi Pelayanan Remaja Sinode GMIM. Sistem Informasi dan teknologi berperan sebagai alat bantu pelaksanaan kegiatan dan menyimpan data sebagai informasi.

Ada tiga hal yang berkaitan dengan penerapan teknologi informasi berbasis computer yaitu perangkat keras (hardware), perangkat lunak (software), dan pengguna (brainware). Ketiga elemen tersebut saling berinteraksi dan dihubungkan dengan suatu perangkat masukan keluaran (input-output media), yang sesuai dengan fungsinya masingmasing. Perangkat keras (Hardware) adalah media yang digunakan untuk memproses 
informasi. Perangkat lunak (software) yaitu sistem dan aplikasi yang digunakan untuk memproses masukan (input) untuk menjadi informasi, sedangkan pengguna (brainware) merupakan hal yang terpenting karena fungsinya sebagai, pengembang hardware dan software, serta sebagai pelaksanan (operator) masukan (input) dan sekaligus penerima keluaran (output) sebagai pengguna sistem (user). Pengguna sistem adalah manusia (man) yang secara psikologi memiliki suatu prilaku (behavior) tertentu yang melekat pada dirinya, sehingga aspek keprilakuan dalam konteks manusia sebagai pengguna (brainware) TI menjadi penting sebagai faktor penentu pada setiap orang yang menjalankan TI.

Kemanfaatan (usefulness) sebagai suatu tingkatan dimana seseorang percaya bahwa penggunaan suatu subyek tertentu akan dapat meningkatkan prestasi kerja orang tersebut. Berdasarkan definisi tersebut dapat diartikan bahwa kemanfaatan dari penggunaan komputer dapat meningkatkan kinerja, prestasi kerja orang yang menggunakannya. Kemanfaatan TI merupakan manfaat yang diharapkan oleh pengguna TI dalam melaksanakan tugasnya. Pengukuran kemanfaatan tersebut berdasarkan frekuensi penggunaan dan diversitas/keragaman aplikasi yang dijalankan. Individu akan menggunakan TI jika mengetahui manfaat positif atas penggunaannya Kemanfaatan juga dapat dibagi kedalam dua kategori, yaitu (1) Kemanfaatan dengan estimasi satu faktor, dan (2) kemanfaatan dengan estimasi dua faktor (kemanfaatan dan efektifitas). Kemanfaatan dengan estimasi satu faktor meliputi dimensi;

a. Menjadikan pekerjaan lebih mudah (makes job easier)

b. Bermanfaat (usefull)

c. Menambah produktifitas (Increase productivity)

d. Mempertinggi efektifitas (enchance efectiveness)

e. Mengembangkan kinerja pekerjaan (improve job performance)

Komisi pelayanan remaja Sinode GMIM merupakan bagian pelayanan Gereja Masehi Injili di Minahasa yang memiliki 974 Jemaat yang tersebar di wilayah Propinsi Sulawesi Utara. Komisi Pelayanan Remaja Sinode GMIM membagi wilayah pelayanan tersebut menjadi 12 Rayon.

\section{B. Masalah}

Permasalahan yang ada dalam pengabdian kepada masyarakat yang dilaksanakan oleh Komisi Pelayanan Remaja Sinode GMIM. Berakar dari permasalahan Pengembangan 
Sistem Informasi yang belum banyak diketahui oleh remaja maupun pembina remaja, sehingga dalam pelaksanaannya masih ada jemaat atau pembina yang belum menggunakan sistem ini. Oleh karena itu pengembangan sistem informasi ini perlu diikuti dengan pelatihan cara menggunakan sistem informasi kegiatan terpadu (SIKAT)

\section{Metode Pelaksanaan}

Salah satu metode yang digunakan adalah metode penelitian grounded research yaitu suatu metode penelitian berdasarkan pada fakta dan menggunakan analisis perbandingan bertujuan untuk mengadakan generalisasi empiris, menetapkan konsep-konsep, membuktikan teori, dan mengembangkan teori dimana pengumpulan data dan analisis data berjalan pada waktu yang bersamaan. Dengan melakukan pengumpulan data/fakta di lapangan akan ditemukan permasalahan-permasalahan yang akan dibuatkan konsep penyelesaiannya.

Tahapan metode pelaksanan kegiatan dibagi menjadi beberapa bagian sebagai berikut:

a. Pengumpulan Data

Metode pengumpulan data dimaksudkan untuk mendapat informasi yang berhubungan dengan pelaksanaan kegiatan pengabdian ini agar tujuan yang akan dicapai dapat terpenuhi.

b. Studi Kepustakaan

Studi kepustakaan dilakukan dengan mencari referensi untuk kebutuhan teoritis tentang kegiatan pengabdian masyarakat ini. Menurut Dewi, et al., (2019: 4) bahwa data sekunder dikumpulkan dari bahan pustaka.

c. Analisis Kebutuhan

Pada tahap ini melakukan analisis terhadap kebutuhan-kebutuhan yang dapat menunjang penerapan kegiatan. Beberapa aspek analisis kebutuhan diantaranya lokasi, perlengkapan, bahan bacaan, peralatan penunjang teknologi informasi, keterampilan dan kuantitas.

d. Tinjauan Lokasi

Tim pengusul melakukan kunjungan ke lokasi kegiatan sebagai bagian dari tahap pelaksanaan sehingga tim dapat mengetahui kondisi lapangan yang akan menjadi tempat pelaksanaan kegiatan. Tinjauan lokasi dapat dilakukan berulang kali untuk menjalin komunikasi interaktif terhadap mitra kegiatan. 


\section{Pembahasan}

Pada pelaksanaan kegiatan, metode penyampaian materi secara langsung dengan peralatan pendukung, diskusi, kelompok, dan studi kasus, dapat membantu peserta lebih memahami materi pelatihan yang disampaikan. Sudah tiga kali dilaksanakan pelatihan penggunaan aplikasi SIKAT yaitu di lokasi sebagai berikut:

- GMIM Eben Haezer Tumpaan berlokasi di Kelurahan Tumpaan Baru, Kecamatan Tumpaan, Kabupaten Minahasa Selatan pada tanggal 30 Maret 2019 dengan jumlah kehadiran sebanyak 121 orang

- GMIM Imanuel Ranowangko berlokasi di Kelurahan Ranowangko, Kecamatan Tombariri, Kabupaten Minahasa Induk pada tanggal 6 April 2019 dengan jumlah kehadiran sebanyak 61 orang

- Pusat Teknologi Informasi dan Komunikasi Bidang Data dan Informasi Kantor Sinode GMIM, kelurahan Talete Dua, Kecamatan Tomohon Tengah, Kota Tomohon pada tanggal 17 September 2019 dengan jumlah kehadiran sebanyak 6 orang.

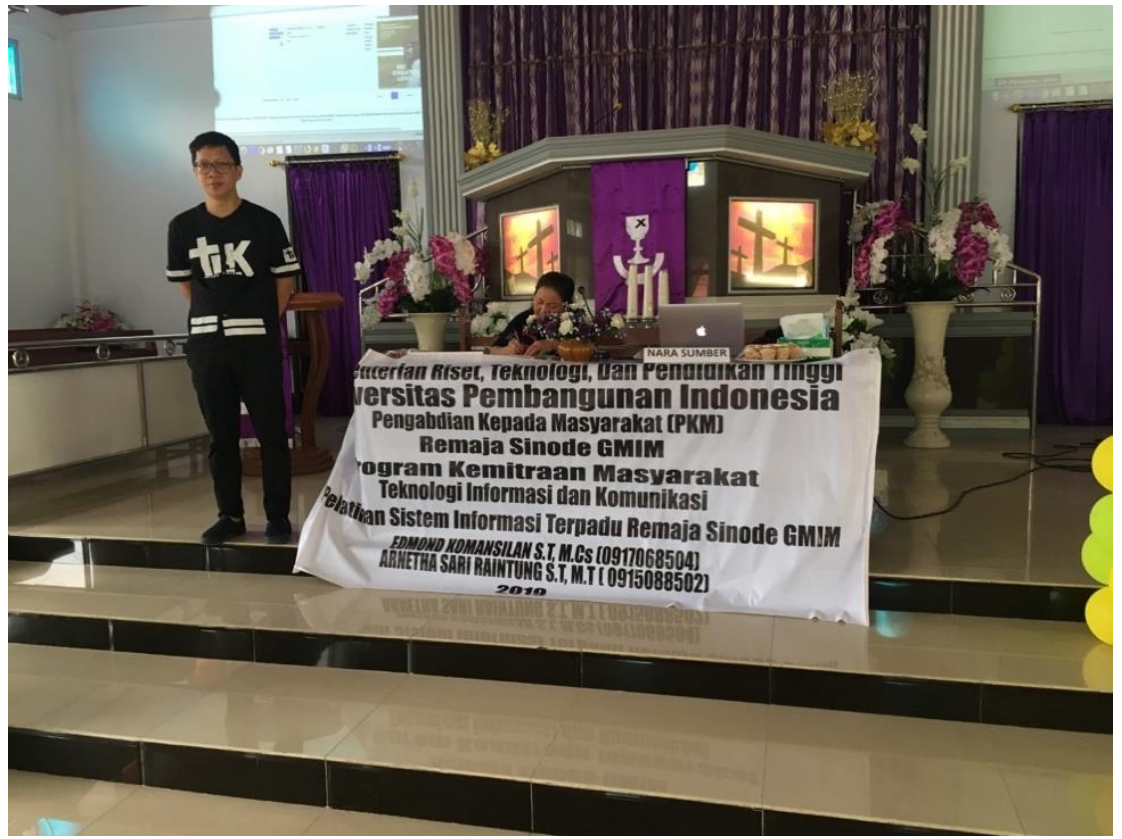

Gambar 1. Pelaksanaan Kegiatan Pelatihan

Juga telah dilaksanakan evaluasi terhadap SIKAT pada tanggal 13 September 2019 di Modoinding Minahasa Selatan, dimana telah diberikan survey penggunaan SIKAT dan telah diisi kuisionernya secara online lewat aplikasi SIKAT oleh para pengguna dengan hasil sebagai berikut: 

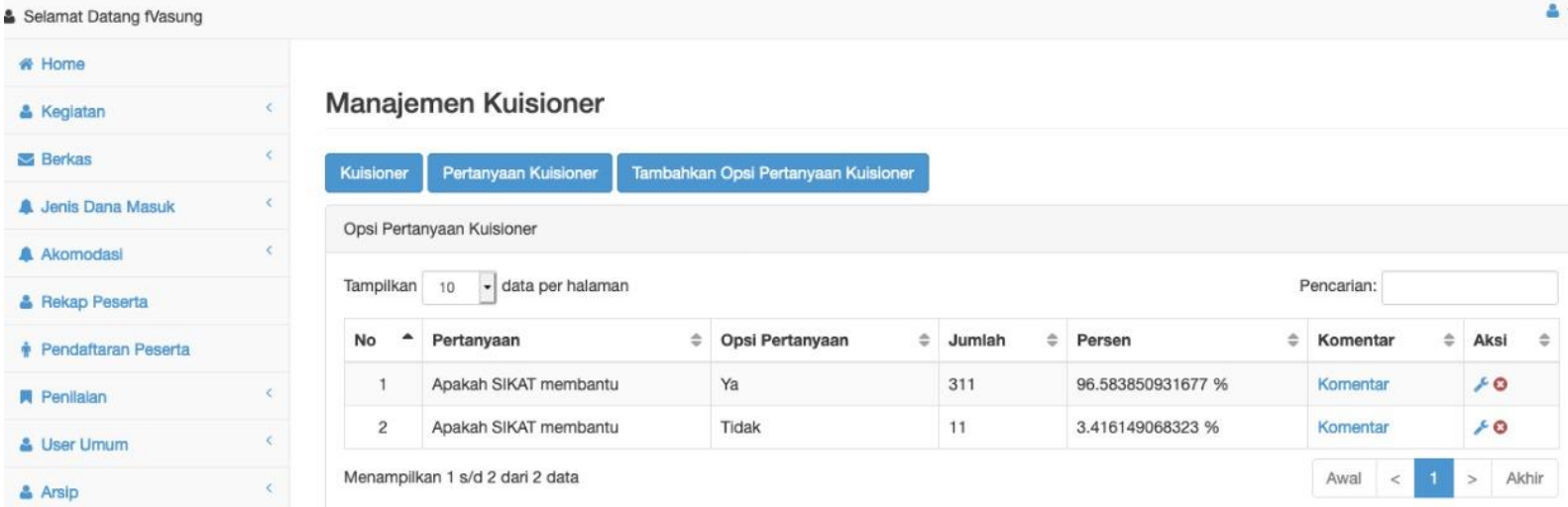

Gambar 2. Kuisioner Penggunaan SIKAT Pertanyaan Satu

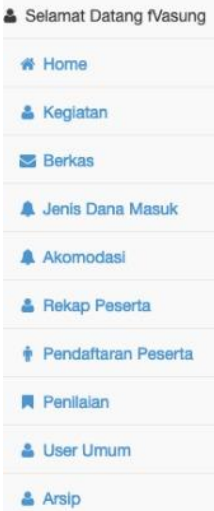

Manajemen Kuisioner
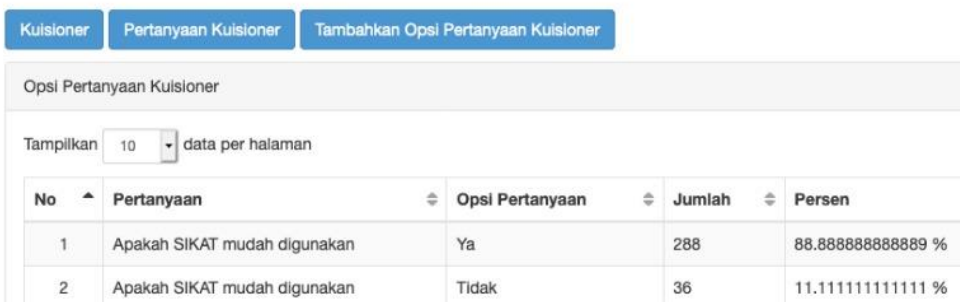

Pencarian:

Komentar $\approx$ Aksi $\approx$

Komentar

Komentar

Menampilikan $1 \mathrm{~s} / \mathrm{d} 2$ darl 2 data

Gambar 3. Kuisioner Penggunaan SIKAT Pertanyaan Dua

\begin{tabular}{|c|c|c|c|c|c|c|c|}
\hline Tampilkan & \multicolumn{3}{|l|}{10 data per halaman } & \multicolumn{4}{|c|}{ Pencari } \\
\hline No $\triangle$ & Pertanyaan & 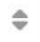 & Opsi Pertanyaan & $\hat{\nabla}$ & Jumlah $\leqslant$ & Persen & 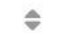 \\
\hline 1 & Halangan dalam penggunaan SIKAT & & Sinyal & & 38 & $80.851063829787 \%$ & \\
\hline 2 & Halangan dalam penggunaan SIKAT & & Gaptek & & 2 & $4.2553191489362 \%$ & \\
\hline 3 & Halangan dalam penggunaan SIKAT & & Tidak Tahu & & 1 & $2.1276595744681 \%$ & \\
\hline 4 & Halangan dalam penggunaan SIKAT & & Malas & & 1 & $2.1276595744681 \%$ & \\
\hline 5 & Halangan dalam penggunaan SIKAT & & Kuota Terbatas & & 0 & $0 \%$ & \\
\hline 6 & Halangan dalam penggunaan SIKAT & & Bingung & & 4 & $8.5106382978723 \%$ & \\
\hline 7 & Halangan dalam penggunaan SIKAT & & Tidak ada halanga & & 1 & $2.1276595744681 \%$ & \\
\hline
\end{tabular}

Gambar 4. Kuisioner Penggunaan SIKAT Pertanyaan Tiga 


\section{E. Kesimpulan}

Adapun hasil dari kegiatan Pengabdian Kepada Masyarakat Remaja Sinode GMIM ini dapat disimpulkan sebagai berikut: (1) Kondisi awal mitra sebelumnya sangat sulit dalam menerapkan peraturan lomba pada saat pendaftaran kegiatan, namun dengan adanya sistem ini maka peraturan lomba tersebut dapat diterapkan dengan baik pada saat pendaftaran kegiatan; (2) Mitra mendapatkan kemampuan dalam menggunakan dan menerapkan sistem informasi kegiatan terpadu tersebut; (3) Dengan adanya sistem yang online ini maka proses pendaftaran kegiatan akan lebih efektif dan efisien.

\section{DAFTAR PUSTAKA}

Amsyah, Zulkifli. (2008). Manajemen Sistem Informasi. Jakarta: Gramedia Pustaka Utama.

Darmawan, Deni. (2012). Pendidikan Teknologi Informasi dan Komunikasi. Bandung: PT. Remaja Rosdakarya Offset

Dewi, I. K., Hardin, Abdullah, L. O. D., Zeldi, L. M. R., Andara, D., Ramadhan, F. M., ... Lembang, H. (2019). The role of forestry police in the prevention and eradication of forest destruction. IOP Conference Series: Earth and Environmental Science, 343(1). https://doi.org/10.1088/1755-1315/343/1/012130

Rizky, Soetam. (2011). Konsep Dasar Rekayasa Perangkat Lunak. Jakarta: Prestasi Pustaka. 